\title{
An Empirical Analysis of Real Estate Residential Investment and Economic Growth - Taking "Shanxi Province" as an Example
}

\author{
Yucong Ye ${ }^{1, a, *}$, Huangjin Liu ${ }^{1, b}$ \\ ${ }^{1}$ Nanjing University of Science and Technology, Xiaoling Wei, Nanjing, China \\ ayucong5161@163.com, bliuhuangjin@hotmail.com \\ *Yucong Ye
}

Keywords: real estate investment; economic growth

\begin{abstract}
This paper take Shanxi Province as an example using unit root test, cointegration test and Granger causality test to analyze the real estate investment and economic growth in Shanxi province. It is found that the real estate investment and economic growth in Shanxi Province are balanced in the long run, and there is a one - way Grange causality. It means that the economic growth in Shanxi Province can significantly promote the growth of real estate residential investment, but it can not lead the local economic growth.
\end{abstract}

\section{Introduction}

With the continuous development of China's economy, the real estate industry is also expanding, In recent years, the real estate industry has gradually become a pillar of national economic growth and leading industries. That real estate in the national economy accounted for such an important position is due to the real estate industry chain effect and the degree of correlation with other industries.

Based on the previous research, this paper takes Shanxi Province as the research object, and makes an empirical analysis on the relationship between real estate investment and economic growth.

\section{Literature review}

In the past, most scholars use regional or national data to study the relationship between real estate investment and economic growth. Qiu Chenghua (2008) used Granger causality test and impulse response function to analyze the real estate investment and economic growth in China. It was concluded that there was a long-term stable equilibrium relationship between real estate development investment and GDP sequence that is balanced. The impact of real estate investment, real estate credit and economic growth has been studied by Kuang Weida using data from 35 large and medium cities in China, and it has been found that the impact of economic growth on real estate investment is greater than that of real estate investment.

\section{An Empirical Analysis of Real Estate Investment and Economic Growth in Shanxi Province}

\subsection{Data selection}

This paper examines the relationship between real estate residential investment and economic growth in Shanxi Province. The selected indicators are GDP, and the real estate investment is selected as the main reference index of real estate investment. (HI) Taking into account the availability of data, the author select the real estate residential investment and Shanxi regional GDP of the time series span of 1995 - 2013.

The data used are from the Shanxi Statistical Yearbook and the National Bureau of Statistics. In order to eliminate the price impact, the author adjust the data to 1990 as the base period. While the 
author make the variables natural logarithm to ensure that the relationship between the variables to eliminate heteroscedasticity.

\subsection{Empirical analysis}

\subsubsection{Test of stationarity of data}

The $\mathrm{c}, \mathrm{t}$, and $\mathrm{k}$ in the test form represent the constant term, the trend term and the lag number respectively. The critical value is the significant level of $1 \%$. The selected lag is the minimum value of AIC and SC. Take the first order difference on the sequence of variables, and denote the second order difference in parentheses. The test results are shown in Table 1:

Table 1 ADF test results

\begin{tabular}{|c|c|c|c|c|c|c|}
\hline variable & $\begin{array}{c}\text { ADF } \\
\text { statistic }\end{array}$ & $\begin{array}{c}\text { Critical } \\
\text { value }\end{array}$ & AIC & SC & $\begin{array}{c}\text { Test form } \\
(\mathrm{c}, \mathrm{t}, \mathrm{k})\end{array}$ & conclusion \\
\hline LNGDP & -1.562121 & -4.571559 & -3.211281 & -3.062885 & $(\mathrm{c}, \mathrm{t}, 0)$ & unstable \\
\hline LNHI & -3.751704 & -4.616209 & -1.228035 & -1.031985 & $(\mathrm{c}, \mathrm{t}, 1)$ & unstable \\
\hline D(LNGDP1) & -2.258339 & -3.886751 & -3.110857 & -3.012832 & $(\mathrm{c}, 0,0)$ & unstable \\
\hline D(LNHI) & -4.156728 & -3.886751 & -0.726574 & -0.628549 & $(\mathrm{c}, 0,0)$ & stable \\
\hline D(LNGDP,2) & -4.336176 & -3.959148 & -2.939618 & -2.798008 & $(\mathrm{c}, 0,1)$ & stable \\
\hline
\end{tabular}

LNGDP and its first-order difference are non-stationary, LNHI is non-stationary, but the two order difference of LNGDP and the first difference of LNHI is absolutely stable (1\%). Therefore, after the first difference of LNGDP (LnGDP (T), -LnGDP (t-1) = LnGDP (T), /GDP (t-1), that is, the growth rate of GDP), and LNHI is the first-order single integral, cointegration analysis can be carried out.

\subsubsection{Cointegration test}

Cointegration test is used to test whether there is a long-term equilibrium between variables. The author select the growth rate of GDP as the dependent variable, HI as an independent variable, using Engle-Granger co-integration test.

(1) regression analysis of D (LNGDP) and LNHI

The fitted equation is obtained:

$\mathrm{D}(\mathrm{LNGDP})=0.067954+0.016119 \mathrm{LNHI}$

(1.654)

$\mathrm{F}=4.585 \mathrm{DW}=1.376$

(2) the unit root test of the residuals of the regression equation. $\mathrm{Ei}, \mathrm{t}=\mathrm{D}$ (LNGDPi, t) 0.067954-0.016119LNHI, and the results are shown in table 2:

Table 2 ADF test results for residual sequence $\mathrm{E}$

\begin{tabular}{|c|c|c|c|c|c|c|}
\hline sequence & $\begin{array}{c}\text { ADF } \\
\text { statistic }\end{array}$ & Test form & $\begin{array}{c}\text { Threshold } \\
(10 \%)\end{array}$ & AIC & SC & $\begin{array}{c}\text { test } \\
\text { results }\end{array}$ \\
\hline $\mathrm{E}$ & -2.796892 & $(\mathrm{C}, 0,0)$ & -2.666593 & -3.232846 & -3.134820 & smooth \\
\hline
\end{tabular}

It can be seen from the test results that the unit root of the equation residual e has an ADF value of -2.796892 , which is less than the critical value of -2.666593. Therefore, the original hypothesis can be rejected at $90 \%$ confidence, indicating that there is no unit root that means a smooth sequence. Thus, through the cointegration test, it shows that there is some long-term equilibrium relationship between the growth rate of GDP in Shanxi Province and the time series of real estate investment.

\subsubsection{Granger causality test}

The above analysis shows that there is some long-term equilibrium relationship between the growth rate of GDP in Shanxi Province and real estate investment. But the causal relationship between the two is not certain. Since the Granger causality test has a greater sensitivity to the selection of lagged variables, it is common to select different lag periods to test and determine the 
robustness of the conclusions. So I use different lag periods as shown in Table 3:

Table 3 Granger test results for DLNGDP and LNHI under different lag periods

\begin{tabular}{|l|l|l|l|l|l|}
\hline Lag & 1 & 2 & 3 & 4 & 5 \\
\hline $\begin{array}{l}\text { LNHI is not the } \\
\text { Granger cause } \\
\text { of DLNGDP }\end{array}$ & 0.1844 & 0.5074 & 0.7171 & 0.9616 & 0.6224 \\
\hline $\begin{array}{l}\text { DLNGDP is not } \\
\text { the Grainger } \\
\text { cause of LNHI }\end{array}$ & 0.8345 & 0.0232 & 0.0683 & 0.0536 & 0.0391 \\
\hline
\end{tabular}

It can be seen from Table 3 that we can't deny that the LNHI is not the original hypothesis of the Granger cause of the DLNGDP at 10\% confidence, regardless of the lag period; except in the case of a lagged period of 1 , the $10 \%$ confidence, It can be rejected that DLNGDP is not the original hypothesis of LNJ's Granger causes.

\section{Conclusions and recommendations}

(1) There is a one-way Grange causality relationship between real estate investment and economic growth in Shanxi Province. We can consider that the economic growth in Shanxi Province can significantly promote the growth of real estate residential investment, but real estate residential investment can not lead the local economic growth.

(2) Under the new requirement of the new economy, Shanxi Province should combine its own advantages to find new economic growth points, play its own cultural industry, tourism industry, optimize and deepen the investment structure, increase the investment of science and technology innovation and allocate resources to promote the sound economic development of Shanxi Province.

\section{References}

[1] Tongxin An, Wan Zhang. Empirical analysis of real estate investment and economic growth [J]. Journal of Jinan University, 2014 (06).

[2] Qingyong Zhang, Huanhuan Zheng. China's residential investment can lead the economic growth [J]. Economic Research, 2012, (02).

[3] Weida Kuang, real estate investment, real estate credit and China's economic growth [J]. Economic Theory and Economic Management, 2011, (01).

[4] Qingfang Wang. China's real estate prices, economic growth and credit expansion research [J]. Finance Research, 2015, (01).

[5] Dengta Chen. Applied econometrics [M]. Beijing: Peking University Press, 2012.

[6] Yuehua Qiu. An Empirical Study on the Relationship between Real Estate Investment and Economic Growth [D]. Yunnan: Yunnan University, 2003 